\title{
Influences of Plateau Zokor Burrowing on Soil Erosion and Nutrient Loss in Alpine Meadows in the Yellow River Source Zone of West China
}

\author{
Guorong $\mathrm{Li}^{1,2,3}$, Xilai $\mathrm{Li}^{1,4, *}$, Jinfang $\mathrm{Li}^{2}{ }^{2}$, Wenting Chen ${ }^{2}$, Haili Zhu ${ }^{2}$, Jianyun Zhao ${ }^{2}$ and \\ Xiasong $\mathrm{Hu}^{1,2}$ \\ 1 State Key Laboratory of Plateau Ecology and Agriculture, Qinghai University, Xining 810016, China; \\ qdliguorong@163.com (G.L.); Huxiasong@sina.com (X.H.) \\ 2 Geological Engineering Department of Qinghai University, Xining 810016, China; qdlijinfang@163.com (J.L.); \\ chenwt77@hotmail.com (W.C.); qdzhuhaili@163.com (H.Z.); zjyunh@163.com (J.Z.) \\ 3 Key Lab of Cenozoic Resource \& Environment in North Margin of the Tibetan Plateau, Xining 810016, China \\ 4 College of Agriculture and Animal Husbandry, Qinghai University, Xining 810016, China \\ * Correspondence: xilai-1i@163.com; Tel.: +86-0971-5318432
}

Received: 21 August 2019; Accepted: 25 October 2019; Published: 28 October 2019

\begin{abstract}
Plateau zokors (Eospalax baileyi) are an agent actively involved in causing soil erosion and meadow degradation in the Yellow River Source Zone of West China. This study aims to quantify the amount of soil and nutrient loss from zokor mounds in relation to slope gradient and rainfall intensity, and to assess the amount of soil loss in zokor-infested areas compared with healthy meadows in Henan County, Qinghai Province. The results showed that zokor mounds were gradually lowered at a rate of $1.8-3.9 \mathrm{~cm} \mathrm{~h}^{-1}$. Soil loss occurred two min after the rain began, reaching the maximum level during the first $20 \mathrm{~min}$. The rate of soil loss and nutrient loss increased with the rainfall intensity and slope gradient. When the rainfall intensity rose from 5 to $10 \mathrm{~mm} \mathrm{~h}^{-1}$, and from 10 to $15 \mathrm{~mm} \mathrm{~h}^{-1}$, the total soil loss on $10^{\circ}$ slopes increased by 2.5 times and 3.9 times, respectively, and soil nutrient loss increased by 1.7 times and 2.7 times, respectively. As the slope gradient steepened to $20^{\circ}$, the corresponding figures were 2.8 times and 4.3 times for total soil loss, and 1.8 times and 2.9 times, respectively, for soil nutrient loss. When the slope rose to $30^{\circ}$, the soil loss increased by 3.0 and 4.5 times, and the soil nutrient loss increased by 1.8 times and 3.1 times, respectively. There was a power function between soil loss and surface runoff $\left(S=0.2371 Q^{2.2307}, R^{2}=0.9529\right)$. The soil was eroded at a rate of $256.6 \mathrm{~g}$ $\mathrm{m}^{-2} \mathrm{~h}^{-1}$ from zokor mounds, 17.7 times higher than in intact meadows, and 1.8 times higher than in partially recovered meadows. Most of the eroded soils had a mean diameter of $0-1.2 \mathrm{~mm}$. It is recommended that artificial control of plateau zokors should be implemented, together with other ecological restoration measures to restrain the soil erosion problem caused by zokor activities.
\end{abstract}

Keywords: plateau zokor mound; soil loss; soil nutrient; rainfall intensity; slope gradient; alpine meadows; Yellow River Source Zone

\section{Introduction}

The Yellow River Source Zone is located in the central Qinghai-Tibetan Plateau and plays a critical role in soil conservation in China [1]. About one third of the vegetation cover in this Zone is alpine meadows, which is one of the most special and vulnerable areas in the Qinghai-Tibet Plateau ecosystem $[2,3]$. They have suffered varying degrees of degradation due to a variety of environmental and anthropogenic factors [4-6]. The degraded grassland accounts for 50\% to $60 \%$ of the available grassland area, and degradation has a tendency to accelerate [7]. The severity of degradation has worsened markedly over the past decade [8], owing to depletion of grass cover and biomass, and the 
disturbance of small mammals. In particular, the burrowing activities by small mammals have a significant impact on meadow soil [9,10]. A large population of small burrowing mammal species, such as the plateau zokor (Eospalax baileyi) and plateau pika (Ochotona curzoniae), has damaged the meadow vegetation $[11,12]$. Their burrowing has enlarged existent denudated patches through the piling of sub-surface soils atop healthy meadows to form mounds of fine sized particles [13]. The most conspicuous effects of plateau zokors on the soil arise from the tailings that they produce while building and maintaining their tunnel systems. It is estimated that the density of plateau zokors is above $20 \mathrm{ha}^{-1}$ [14], and mound density can reach up to $374 \mathrm{ha}^{-1}$ [15], while a plateau zokor deposits at least $1024 \mathrm{~kg} \mathrm{year}^{-1}$ at the soil surface of alpine meadows [16]. Rodent burrowing activities have altered the original soil structure and vegetation community of the meadows [17], and changed soil nutrient contents $[18,19]$. More critically, the mounds comprising loosened soil materials are easily erodible, which can cause serious soil conservation problems and accelerate meadow degradation [20-22]. Based on a survey, about 325.33 million hectares of meadows have been damaged by small mammal activities, accounting for $23.29 \%$ of the total degraded areas in the Yellow River Source Zone [23].

The Yellow River Source Zone has a semi-arid climate with an annual precipitation from 250 to $750 \mathrm{~mm}$, most of which occurs as heavy rainfall during the summer months when zokor burrowing is the most active. Precipitation is an important controller of surface runoff and erosion on hillslopes [24-26], and hence is an important factor in exacerbating the loss of the loosened subsurface soil and nutrients in alpine meadows where mammal burrowing activities are widespread. The amount of soil loss from the mounds is related to a number of variables, such as rainfall intensity and duration, surface cover, topography, and soil particle size.

So far, a number of studies have been carried out to examine the soil erosion processes under different precipitation regimes [27-29]. Most of these studies were implemented in the laboratory, where rainfall duration and intensity can be easily controlled in the simulation experiments [30-33]. Some of the studies have revealed that little runoff and no erosion occur on a steep runoff plot of permanent grassland [34], and vegetation cover and type are the dominant factors in reducing surface runoff and soil loss [35,36]. Under special climatic conditions, rodent activities accelerate the soil loss rate $[37,38]$. A number of authors have described the processes of soil erosion on bare slopes and loose soils $[39,40]$. It has been ascertained that zokors can cause the formation of denuded patches in meadows and accelerate soil erosion [41,42]. It has been confirmed that rodent activities are the main driver of soil erosion in meadows [43]. However, nobody has quantified the loss of soil from meadows triggered by plateau zokor burrowing compared with healthy meadows. Besides, the findings of existing studies are not directly applicable to alpine meadows full of zokor mounds formed by zokor digging. The soil particles are easily eroded by rainwater [44-46]. However, the actual loss of soil and soil nutrients from zokor-damaged alpine meadows has not been investigated in the field. On the other hand, the results obtained from the indoor simulations may not truly reflect the actual effects of zokor burrowing on soil erosion in alpine meadows, and the rate of soil and nutrient lost from the alpine meadows still remains unknown.

This study attempts to fill these knowledge gaps and quantify the influences of zokor burrowing on soil and nutrient loss in the alpine meadows of the Yellow River Source Zone under different precipitation regimes. The specific objectives are fourfold: (1) to quantify the amount of soil loss under various precipitation intensities and durations; (2) to establish the quantitative relationship between slope gradient and particle size of the eroded soils; (3) to examine the relationship between the quantity of eroded soil and surface runoff in zokor-infested meadows; and (4) to explore how zokor damage accelerates soil loss from degraded meadows in comparison with that from intact meadows.

The novelty of this study lies in the use of freshly formed zokor mounds that have not been subject to any human disturbance. Thus, the obtained results are very close to the reality. In addition, the simulated precipitation intensity is based on the observed precipitation events during the formative period of fresh zokor mounds. These settings should yield more realistic results than laboratory-based experiments. These results can deepen our understanding of the actual contribution of zokor burrowing 
to soil loss in alpine meadows. This study is significant in that the surface geomorphology of the zokor mounds and zokor damage characteristics, together with the local meteorological data, can be used to predict the annual average erosion rate of alpine meadows caused by rodents in the study area. It can also reveal the process and mechanism of soil erosion in this area, and provide important guidance for alpine meadow vegetation restoration and ecological protection on the Qinghai-Tibet Plateau.

\section{Study Area}

The study area is located in Henan County, Qinghai Province in the Yellow River Source Zone $\left(34.7333^{\circ}, 101.7833^{\circ}\right.$, WGS$\left.^{\circ}\right)$. It has an average altitude of about $3,600 \mathrm{~m}$ above sea level (Figure 1$)$. Its annual temperature averages $-1.3-1.6^{\circ} \mathrm{C}$, and annual precipitation $597.1-615.5 \mathrm{~mm}(281.7-362.6 \mathrm{~mm}$ mainly during June-September according to the local meteorological data). During November-April, the area is cold, dry, and windy with the maximum wind speed being up to $23.7 \mathrm{~m} \mathrm{~s}^{-1}$. Major land cover in the study area is alpine meadows, which are widely distributed throughout the Source Zone. The dominant species of grasses are Kobresia humilis, K. capillifolia, and K. pygmaea. Some of the meadows have suffered severe degradation where most of the original vegetation disappeared. Incidentally, these areas also have a high density of zokor mounds, which have a semi-circular surface of a non-uniform slope that can be as steep as $45^{\circ}$ and is much gentler near the apex. Their height averages about $25 \mathrm{~cm}$, with a diameter of around $30-50 \mathrm{~cm}$. The ground at which the mounds are located has a gradient between 0 and $30^{\circ}$. The harsh climate and fragile meadow eco-system, coupled with the loosened zokor mounds, creates a setting extremely vulnerable to soil erosion and nutrient depletion during the summer months when intensive zokor burrowing activities coincide with relatively heavy rains.

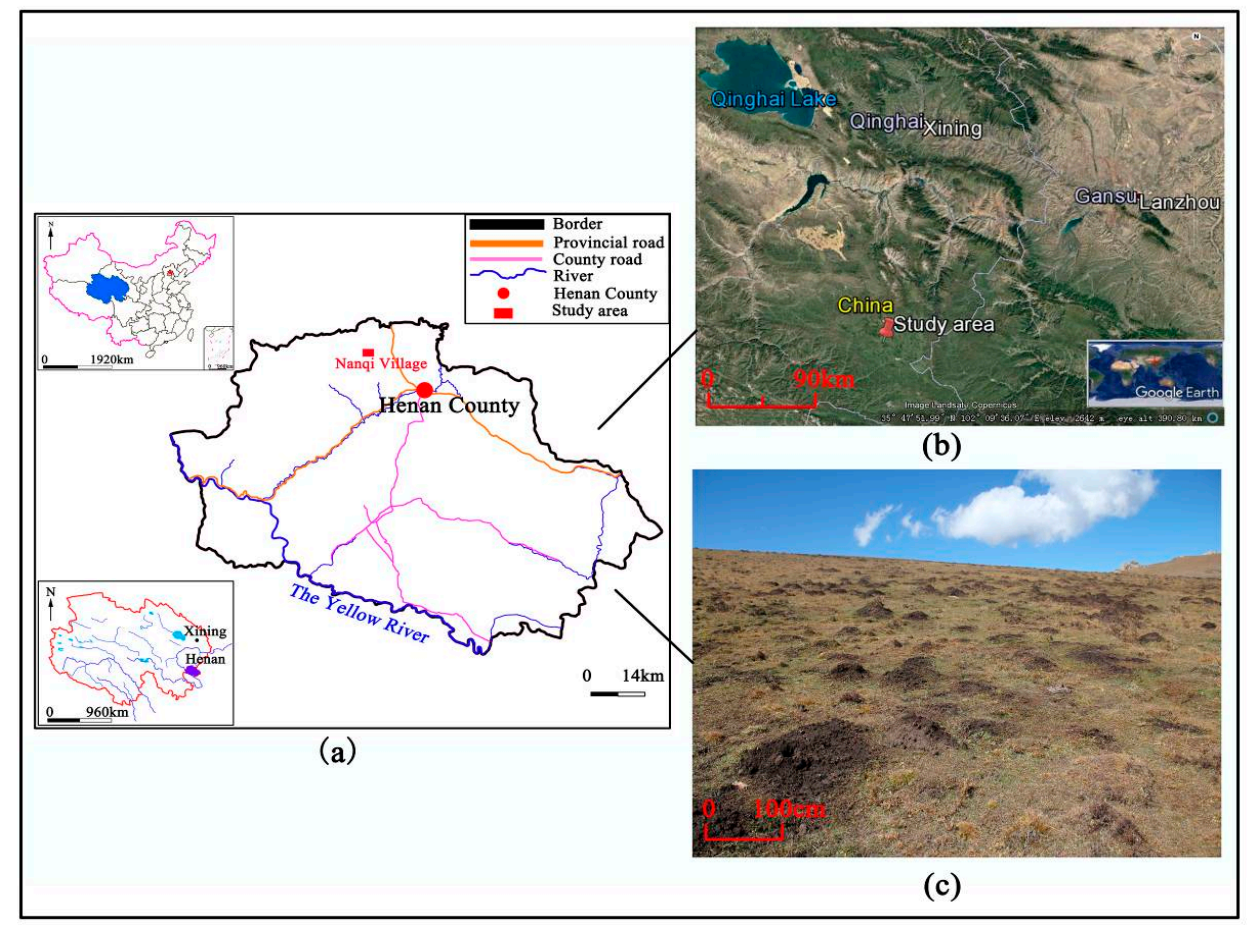

Figure 1. (a) Location of the study area; (b) An aerial image of the study area; (c) Ground photo of the study area.

\section{Methodology}

\subsection{Site Selection}

A reconnaissance excursion to the study area was undertaken during 10-30 August of 2018, during which the dense zokor-induced subsoil mounds were located in places where precipitation was the 
most concentrated and soil erosion was the most serious. In total, 27 identical sampling plots of $2 \mathrm{~m}$ by $2 \mathrm{~m}$ in size were set up in an area of $300 \mathrm{~m}$ by $450 \mathrm{~m}$. Each sampling plot was centered around only one fresh and relatively isolated mound of a similar size and age (Figure 2a). One third of the 27 sampling plots had one of the three slope gradients of $10^{\circ}, 20^{\circ}$, and $30^{\circ}$ (nine sampling plots had one of the three identical slope gradients). The sampling plots were randomly set up from the foot to the middle of a slope, and the interval between adjacent sampling plots was set at more than $20 \mathrm{~m}$ (Figure 3). In order to assess the influence of zokor activities on soil loss from the meadow, three more sites of the same $20^{\circ}$ gradient were selected for comparison. They represented a formerly degraded but now vegetation-recovered site (Figure $2 b$ ), and a healthy meadow site (Figure $2 c$ ). The vegetation-recovered site used to be denudated, but now vegetation has recovered naturally to a cover of $60 \%$.

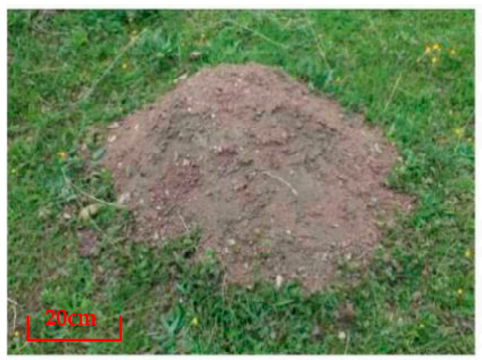

(a)

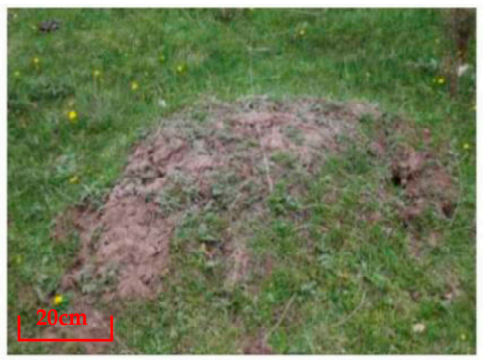

(b)

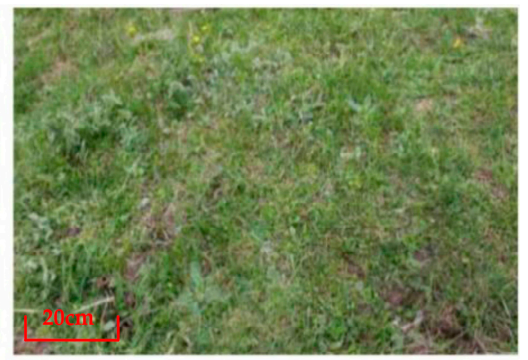

(c)

Figure 2. Sampling sites of (a) zokor mound; (b) vegetation-recovered site; and (c) healthy meadow. Sampling plots have a size of $2 \mathrm{~m}$ by $2 \mathrm{~m}$, centred around the mound.

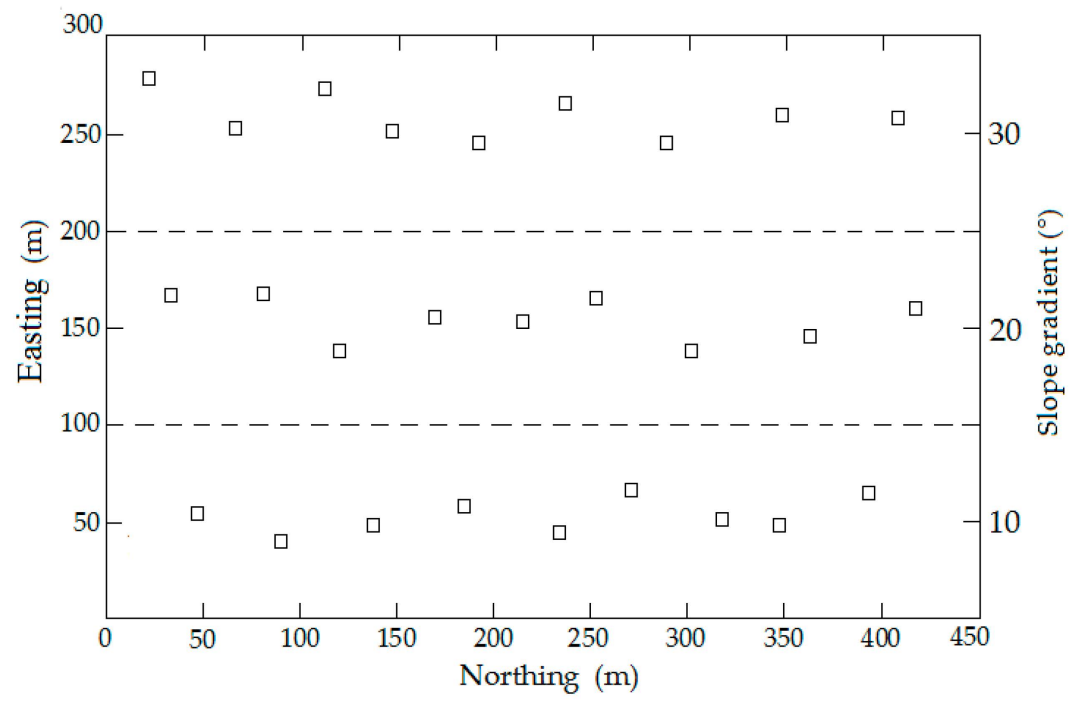

Figure 3. Distribution of sampling plots and their slope gradients.

\subsection{Precipitation Intensity}

After the sampling plots were properly selected, an artificial precipitation simulator was set up to produce one of three precipitation intensities of $5 \mathrm{~mm} \mathrm{~h}^{-1}, 10 \mathrm{~mm} \mathrm{~h}^{-1}$, and $15 \mathrm{~mm} \mathrm{~h}^{-1}$. These intensities were determined based on historic hourly records of precipitation and runoff intensity in the study area over the previous two years.

Preliminary experiments in the field indicated that surface runoff rarely formed when precipitation intensity fell below $2 \mathrm{~mm} \mathrm{~h}^{-1}$. The precipitation mainly occurred during June-September of each year based on the local meteorological data (Figure 4), and the historic records showed that no precipitation events exceeded the intensity of over $20 \mathrm{~mm} \mathrm{~h}^{-1}$. All precipitation intensities fell into three categories of 3-7 $\mathrm{mm} \mathrm{h}^{-1}, 8-12 \mathrm{~mm} \mathrm{~h}^{-1}$, and over $15 \mathrm{~mm} \mathrm{~h}^{-1}$. Thus, the simulated rainfall events were set to 
5,10 , and $15 \mathrm{~mm} \mathrm{~h}^{-1}$. These figures were very close to the average precipitation intensities of the three categories.

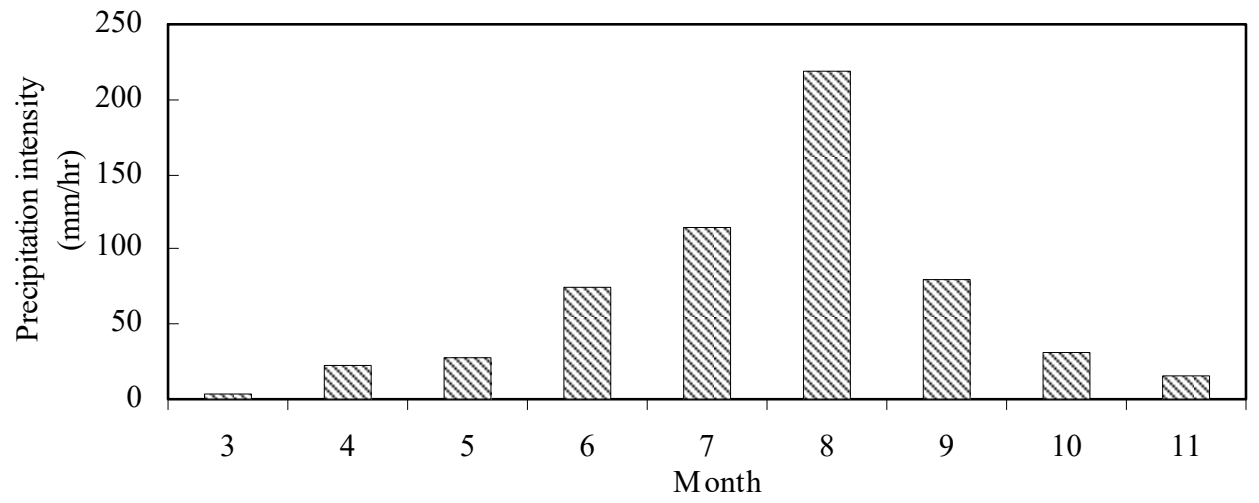

Figure 4. Distribution characteristics of rainfall intensity in test area (Data from the weather station in the test area, 2017).

\subsection{Rainfall Simulation}

The rainfall simulator used is composed of a solid umbrella sprinkler, a pump, a precipitation intensity regulator, a guide tank, and a beaker (Figure 5a). Its nozzle has a hemispheric shape with a diameter of $3 \mathrm{~cm}$, and it evenly dispenses water from holes $1 \mathrm{~mm}$ in diameter. The simulator was such placed so that its nozzle was $3 \mathrm{~m}$ above the center of the sampling plot. The effective diameter of precipitation was $3.5 \mathrm{~m}$ when the water was sprayed downwards, and the simulated precipitation had a precision of $\pm 0.5 \mathrm{~mm} \mathrm{~min}^{-1}$. The regulator could control the precipitation intensity and maintain it at 0-60 $\mathrm{mm} \mathrm{h}^{-1}$. The water pump, water conveyance pipe, and the precipitation device were connected to a water source. The pump's inlet water pipe was extended below the water surface, and a filter net was placed on the inlet cover to prevent soil particles from entering the pump pipe. Once the pump was turned on, water was evenly sprayed to the ground through the nozzle.

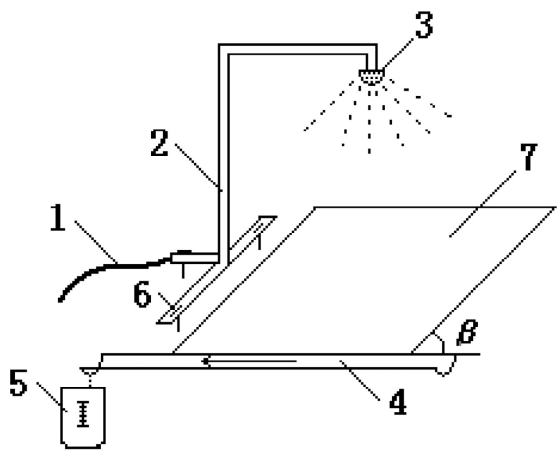

(a)

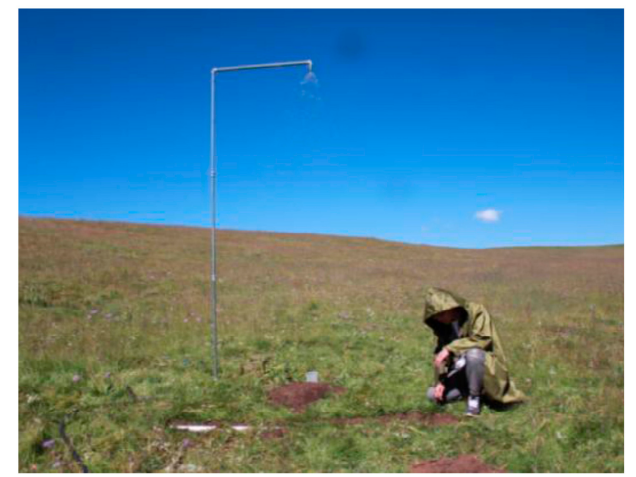

(b)

Figure 5. A schematic diagram of the precipitation simulator (a) and its deployment in the field (b): 1. Water delivery pipe; 2 . Support tube; 3. Solid umbrella sprinkler; 4 . Guide tank; 5. Beaker; 6. Ground anchor; 7 . Plots; $\beta$-Slope gradient.

Field investigations and test results show that the raindrops sprayed from the simulated rainfall device were approximately free-falling, while the kinetic energy of the raindrops reaching the surface was different when the precipitation height changed. In order to realize the similarity between the kinetic energy of simulated and natural rainfall, each test was tested. A test panel (touches raindrops, test area $50 \mathrm{~cm}$ by $50 \mathrm{~cm}$ ) on the soil surface was installed at the top of a digital display intensity sensor, which was set on the ground. The kinetic energy of simulated and natural rainfall per second was 
obtained when rainfall occurred. After repeated tests, the impact intensity of simulated precipitation on the surface was similar to that of natural rainfall when the height of the solid umbrella sprinkler was about $3 \mathrm{~m}$ (Table 1), and the raindrops were similar in size. Therefore, the precipitation height was set to $3 \mathrm{~m}$ in the simulation tests.

Table 1. Impact intensity of natural and simulated rainfall on the soil surface per second.

\begin{tabular}{ccccc}
\hline $\begin{array}{c}\text { Precipitation } \\
\text { Intensity } \\
\left(\mathbf{m m ~ h} \mathbf{~}^{\mathbf{1}}\right)\end{array}$ & Precipitation Type & $\begin{array}{c}\text { Number of } \\
\text { Samples } \\
\mathbf{( n )}\end{array}$ & $\begin{array}{c}\text { Raindrop } \\
\text { Diameter } \\
\mathbf{( m m})\end{array}$ & $\begin{array}{c}\text { Impact Intensity on } \\
\text { the Soil Surface } \\
\mathbf{( P a )}\end{array}$ \\
\hline \multirow{2}{*}{5} & Natural rainfall & 30 & $3.48 \pm 0.26$ & $0.46 \pm 0.08$ \\
\cline { 2 - 5 } & Simulated rainfall & 30 & $3.46 \pm 0.22$ & $0.47 \pm 0.12$ \\
\hline \multirow{2}{*}{10} & Natural rainfall & 30 & $3.52 \pm 0.24$ & $1.01 \pm 0.16$ \\
\cline { 2 - 5 } & Simulated rainfall & 30 & $3.48 \pm 0.32$ & $0.98 \pm 0.08$ \\
\hline \multirow{2}{*}{15} & Natural rainfall & 30 & $3.56 \pm 0.36$ & $1.79 \pm 0.10$ \\
\cline { 2 - 5 } & Simulated rainfall & 30 & $3.52 \pm 0.28$ & $1.81 \pm 0.14$ \\
\hline
\end{tabular}

To set up the simulator, a pit of $20 \mathrm{~cm}$ deep was first excavated in close proximity to the mound edge. A plastic sheet was used to join the upper part of a U-shaped trough to the mound. It was tilted slightly in order to ensure that water in the flume flowed only to one end, under which a beaker was placed to collect the runoff and eroded soils. Over the entire rainfall test, the moving distance of soil particles at each plot was about $1.5 \mathrm{~m}$, which can cause the soil to be lost from the plot, and transported to a downstream river by surface runoff. Therefore, the soil that was transported by $1.5 \mathrm{~m}$ in this experiment was regarded as the amount of soil lost from the plot. The trough was covered with a plastic sheet in order to prevent raindrops from falling directly into the guide tank and interfacing with the runoff experiment. After the precipitation intensity was adjusted to the desired level and stabilized, the sprinkler head was extended over the sampling plot (Figure 5b). Each precipitation intensity was repeated three times in three identical sampling plots, and all test data were statistically analyzed using SPSS (Statistical Program for Social Sciences).

Prior to the precipitation simulation, a calibrated drill rod with a diameter of $0.5 \mathrm{~cm}$ was inserted into the center of the zokor mound to measure the change in its height in relation to precipitation duration. The same precipitation simulation was repeated three times, each time with one of the three slope gradients (to achieve objective 2), and with one of the three precipitation intensities (to achieve objective 1), resulting in a total of 27 experiments. The three results from the same intensity and slope gradient were averaged to yield the final result. In each simulation the rainfall event lasted for one hour, during which surface runoff was collected at an interval of five min, together with the eroded soils. The latter was separated from the runoff subsequently using a paper filter. The particle size composition of the isolated soils was determined using an intelligent laser particle size analyzer (Winner 2308 type) in the temporal sequence of erosion. Afterwards, the soils were dried at the room temperature for one week. The dried soils were weighted, and their nutrient content was analyzed in the laboratory.

The analyzed soil nutrients included soil organic matter (Potassium dichromate volume method), humus (Potassium dichromate oxidation method), total N (Potassium dichromate-sulfuric acid digestion method), total P (Sulfuric acid - Perchloric acid digestion method), total $\mathrm{K}(\mathrm{NaOH}$ Melting-Flame Photometer Method), alkaline hydrolysis N (Alkali diffusion method), available P (Sodium bicarbonate dissolution method), available $\mathrm{K}$ (Ammonium acetate-flame photometer method) [47]. The same analysis was replicated ten times for the same samples collected from the same mound, and the average was used as the final result.

In addition, three identical experiments were carried out, one for each type of surface covers (denudated mounds, partially recovered meadow, and healthy meadow of no degradation), and the 
average was used as the final result. In all the experiments, the simulated rainfall intensity was controlled at $10 \mathrm{~mm} \mathrm{~h}^{-1}$ for one hour and all the sites had the same slope gradient of $20^{\circ}$.

\section{Results}

\subsection{Change in Mound Surface Morphology}

The zokor mounds were easily reshaped in their surface morphology by precipitation after the fine sediment particles were removed. Taking the $30^{\circ}$ mound as an example, after $10 \mathrm{~min}$ of rain at an intensity of $15 \mathrm{~mm} \mathrm{~h}^{-1}$, the surface materials became much coarser in texture after fine silts had been eroded downslope (Figure 6a). Only the coarse gravels and even pebbles were left behind at the end of the rain event (Figure 6b). Removal of the soil exposed the underlying layer that was more resistant to erosion due to the binding effect of the chaotic grass roots. The loss of the soil particles was the most active after 5-10 min of precipitation, after which the erosion rate was much lower as the sandy and gravel materials with a much larger diameter were heavier and more resistant to erosion. As expected, the mean diameter expanded by $4.8 \mathrm{~cm}$ within $60 \mathrm{~min}$, and the height of the zokor mound was lowered gradually and continuously during the simulated rainfall event (Figure 7). The rate of decrease $\left(3.9 \mathrm{~cm} \mathrm{~h}^{-1}\right)$ was especially pronounced during the first $20 \mathrm{~min}$. Afterwards, the rate of decrease was more gradual at $1.8 \mathrm{~cm} \mathrm{~h}^{-1}$. The explanation for the decrease is the removal of fine soils that make up a large majority of the mound material.

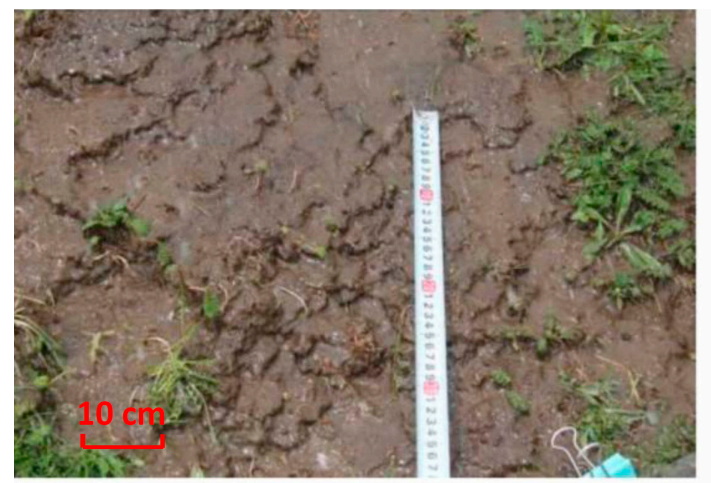

(a)

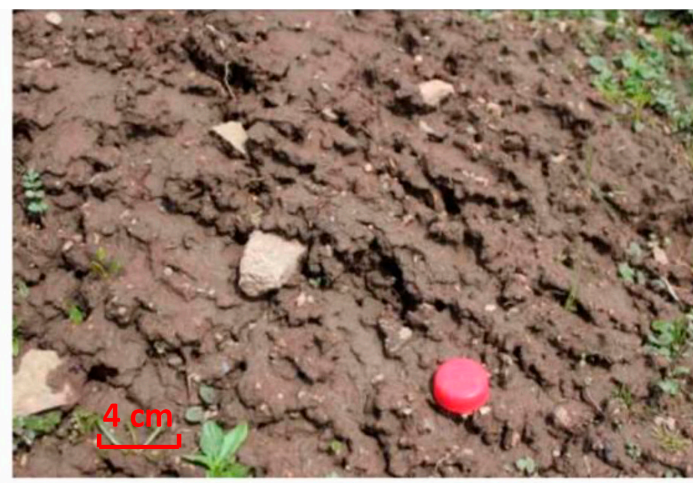

(b)

Figure 6. Evolving surface texture of the mound surface during and after the rainfall experiment ((a) 10 min into the rain event, (b) At the end of the rain event).

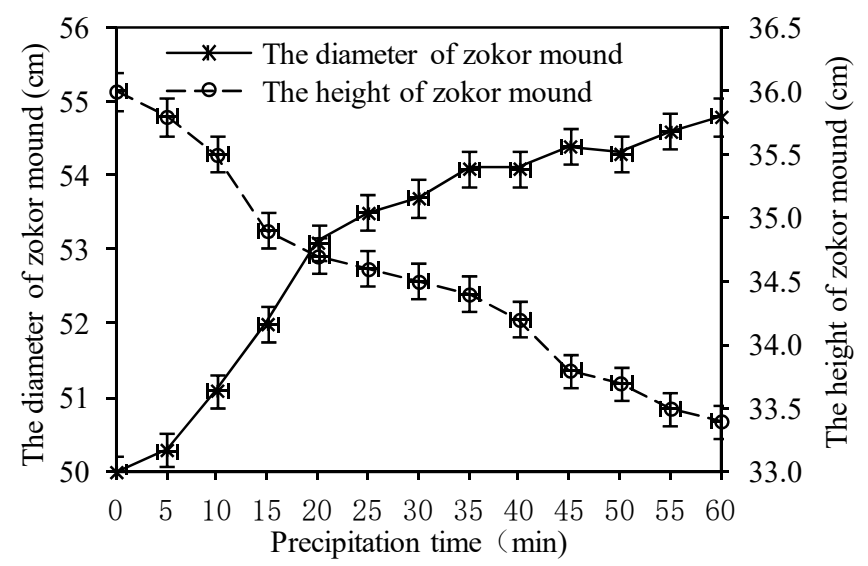

Figure 7. Variation in the diameter (left axis, solid line) and height (right axis, dashed line) of zokor mounds with precipitation. Results are based on a rainfall intensity of $15 \mathrm{~mm} \mathrm{~h}^{-1}$ on a $30^{\circ}$ slope. 
As the rain event prolonged, the overall shape of the mound evolved gradually from a semi-circle to a flattened circle. After $60 \mathrm{~min}$ of rain, the mean slope of the mound was reduced from $45^{\circ}$ to $20^{\circ}-30^{\circ}$. In addition, a small quantity of relatively large particles had been transported from the apex of the mound to its lower border by the surface runoff. Only fine particles (including those formed by the splashing raindrops) had been eroded away from the mound. These processes explained why the mound height was reduced while its mean diameter expanded by $4.8 \mathrm{~cm}$ within $60 \mathrm{~min}$. The two were correlated negatively at a coefficient of 0.9645 . The relationship between the diameter (D) of the mound and rainfall duration ( $\mathrm{T}$ ) could be described as a power function:

$$
\mathrm{D}=49.438 \mathrm{~T}^{0.0407}\left(\mathrm{R}^{2}=0.9544\right)
$$

The relationship between the height $(\mathrm{H})$ and diameter $(\mathrm{D})$ of the mound could be described as a linear function:

$$
\mathrm{H}=-0.0426 \mathrm{D}+35.818\left(\mathrm{R}^{2}=0.9651\right)
$$

\subsection{Impact of Surface Gradient and Precipitation Intensity}

Soil erosion took place two min after the rain started, regardless of the surface gradient (Figure 8). Initially, the quantity of eroded soils increased rapidly with time, culminating at $10 \mathrm{~min}$. Afterwards, it started to decrease gradually with time. Both the rate of rapid increase and the gradual decrease were related closely to rainfall intensity. The time to reach the peak erosion was increased from $15 \mathrm{~min}$ to $20 \mathrm{~min}$ as the rainfall intensified from $5 \mathrm{~mm} \mathrm{~h}^{-1}$ to $15 \mathrm{~mm} \mathrm{~h}^{-1}$. However, there was little difference in reaching the peak erosion between the $10 \mathrm{~mm} \mathrm{~h}^{-1}$ and $15 \mathrm{~mm} \mathrm{~h}^{-1}$ intensities. Furthermore, the discrepancy in the amount of eroded soils between $10 \mathrm{~mm} \mathrm{~h}^{-1}$ and $15 \mathrm{~mm} \mathrm{~h}^{-1}$ was smaller than that between $5 \mathrm{~mm} \mathrm{~h}^{-1}$ and $10 \mathrm{~mm} \mathrm{~h}^{-1}$. For instance, the peak erosion was at $196.47 \mathrm{~g}$ with the $15 \mathrm{~mm} \mathrm{~h}^{-1}$ rain on the $10^{\circ}$ slope. It decreased slightly to $138.56 \mathrm{~g}$ with the $10 \mathrm{~mm} \mathrm{~h}^{-1}$ rain, a reduction of about $29.5 \%$. In contrast, the peak erosion reached only $50.07 \mathrm{~g}$ with the $5 \mathrm{~mm} \mathrm{~h}^{-1}$ rain (a reduction of about $63.9 \%$ ). Therefore, the intensity of $10 \mathrm{~mm} \mathrm{~h}^{-1}$ was the most influential to the rate of soil erosion because it also varied the most with the rainfall duration among the three rainfall intensities studied. Consequently, the amount of eroded soils was almost the same as that of the $5 \mathrm{~mm} \mathrm{~h}^{-1}$ at the end of the simulation (e.g., $60 \mathrm{~min}$ ).

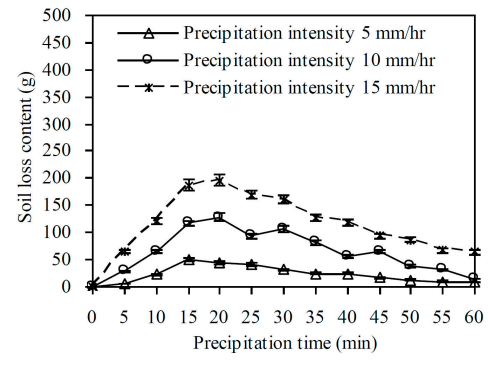

(a) $10^{\circ}$

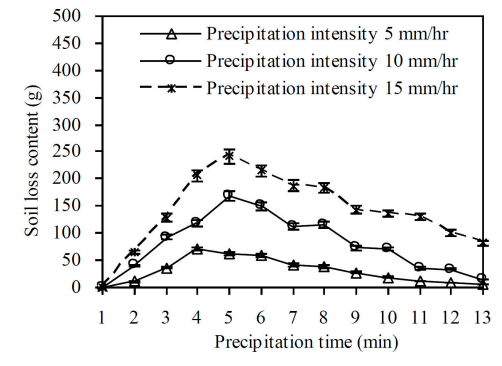

(b) $20^{\circ}$

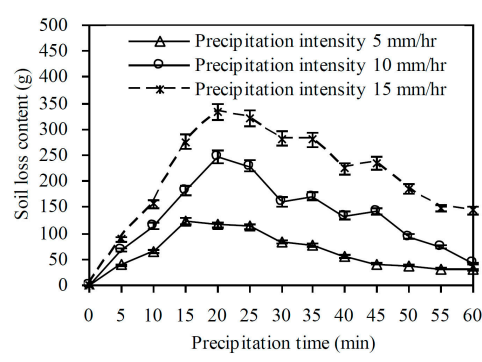

(c) $30^{\circ}$

Figure 8. The variation of soil loss at three rainfall intensities with rainfall duration on slopes of three gradients.

Apart from rainfall intensity, the amount of soil loss also notably increased with slope gradient. As the slope gradient rose from $10^{\circ}$ to $20^{\circ}$, the peak erosion rate hardly changed at the rainfall intensity of $10 \mathrm{~mm} \mathrm{~h}^{-1}$, but it rose from $50.07 \mathrm{~g}$ to over $71.54 \mathrm{~g}$ at the rainfall intensity of $5 \mathrm{~mm} \mathrm{~h}^{-1}$, and from $196.47 \mathrm{~g}$ to $241.35 \mathrm{~g}$ at the intensity of $15 \mathrm{~mm} \mathrm{~h}^{-1}$. As the slope gradient further steepened to $30^{\circ}$, the peak erosion increased at all the three rainfall intensities. The increase was the highest to $124.9 \mathrm{~g}$ for the $5 \mathrm{~mm} \mathrm{~h}^{-1}$ intensity, nearly the same as the $10 \mathrm{~mm} \mathrm{~h}^{-1}$ rainfall intensity on $10^{\circ}$ slopes, even though it took a bit longer to reach this level. Moreover, the erosion rate decreased with time at a slower pace than on slopes of a gentler gradient. 
Over the entire rainfall event (e.g., $60 \mathrm{~min}$ ), at the same slope of $10^{\circ}$, the total loss of soils increased 2.5 times and 3.9 times as rain intensified from 5 to $10 \mathrm{~mm} \mathrm{~h}^{-1}$ and $15 \mathrm{~mm} \mathrm{~h}^{-1}$, respectively (Figure 9). The corresponding figures are 2.8 times and 4.3 times on $20^{\circ}$ slopes, and 3.0 and 4.5 times on $30^{\circ}$ slopes. In addition, at the same rainfall intensity of $5 \mathrm{~mm} \mathrm{~h}^{-1}$, a total of $295.39 \mathrm{~g}$ of soils was lost from the $10^{\circ}$ slopes. This loss rose to $361.69 \mathrm{~g}$ and $615.78 \mathrm{~g}$ when the slopes gradient increased to $20^{\circ}$ and $30^{\circ}$, respectively (Figure 9). The total amount of eroded soils from the mounds was linearly and positively related to slope gradient and the rainfall intensity except at $30^{\circ}$ with the $15 \mathrm{~mm} \mathrm{~h}^{-1}$ rain at which the rate of increase appeared to be exponential. It was found that the number of plateau zokor mounds was more than 450 within an area of $300 \mathrm{~m}$ by $450 \mathrm{~m}$. The rate of soil loss reached up to $186.1 \mathrm{~kg} \mathrm{~h}^{-1}$ at a rainfall intensity of $5 \mathrm{~mm} \mathrm{~h}^{-1}$. The corresponding figure is $545.3 \mathrm{~kg} \mathrm{~h}^{-1}$ and $820.3 \mathrm{~kg} \mathrm{~h}^{-1}$ at the intensity of $10 \mathrm{~mm} \mathrm{~h}^{-1}$ and $15 \mathrm{~mm} \mathrm{~h}^{-1}$, respectively. Soil erosion occurred mainly in June and September.

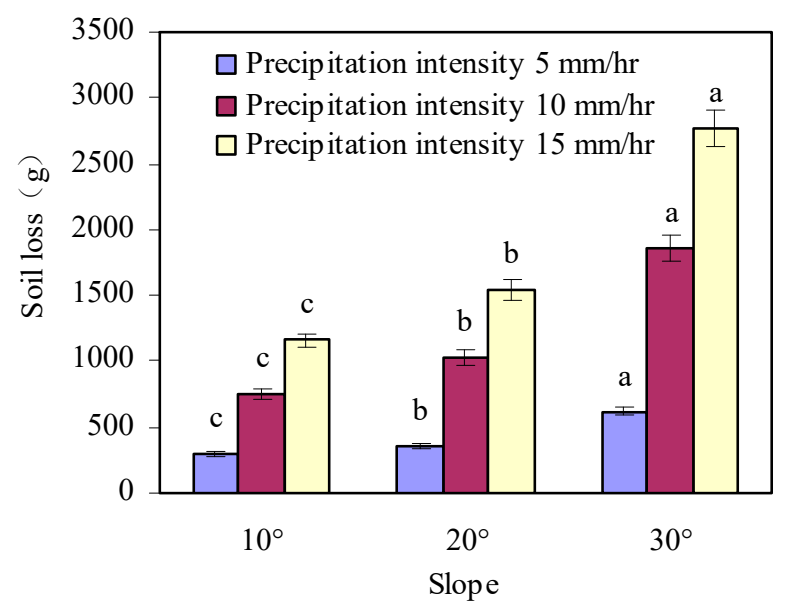

Figure 9. The total soil loss in relation to slope gradient at three rainfall intensities over the entire rain event (e.g., $60 \mathrm{~min})$.

\subsection{Loss of Soil Nutrients}

As with soil loss, the loss of soil nutrients from the zokor mounds varied with slope gradient and rainfall intensity (Table 2). Under the same rain conditions, total nitrogen, total phosphorus, total potassium, alkali-hydrolyzed nitrogen, available phosphorus, available potassium, and organic matter of soil all increased with slope gradient. As the slope gradient increased from $10^{\circ}$ to $20^{\circ}$ and from $20^{\circ}$ to $30^{\circ}$, the average soil nutrient loss increased 1.3 times to 1.7 times, at the rainfall intensity of $5 \mathrm{~mm} \mathrm{~h}^{-1}$, and 1.3 and 1.8 times, respectively, at the rainfall intensity of $10 \mathrm{~mm} \mathrm{~h}^{-1}$. At the rainfall intensity of $15 \mathrm{~mm} \mathrm{~h}^{-1}$, average nutrient loss increased 1.3 times and 1.9 times, respectively. When the precipitation intensity increased from 5 to $10 \mathrm{~mm} \mathrm{~h}^{-1}$ and from 10 to $15 \mathrm{~mm} \mathrm{~h}^{-1}$, the soil nutrient loss on $10^{\circ}$ slopes increased 1.7 times and 2.7 times, respectively. On $20^{\circ}$ slopes, the soil nutrient loss increased 1.8 times and 2.9 times, respectively; and on $30^{\circ}$ slopes, the soil nutrient loss increased 1.8 times and 3.1 times, respectively. These changes indicated the existence of a positive correlation between soil nutrient loss and slope gradient. 
Table 2. Soil nutrient loss with slope gradient and precipitation intensity.

\begin{tabular}{|c|c|c|c|c|c|c|c|c|}
\hline Slope & $\begin{array}{c}\text { Precipitation } \\
\text { Intensity }\left(\mathrm{mm} \mathrm{h}^{-1}\right)\end{array}$ & $\begin{array}{l}\text { Total N } \\
\text { (g) }\end{array}$ & $\begin{array}{c}\text { Total P } \\
\text { (g) }\end{array}$ & $\begin{array}{l}\text { Total K } \\
\text { (g) }\end{array}$ & $\begin{array}{l}\text { Alkali-hydrolyzed N } \\
\text { (g) }\end{array}$ & $\begin{array}{c}\text { Available P } \\
\text { (mg) }\end{array}$ & $\begin{array}{c}\text { Available K } \\
\text { (g) }\end{array}$ & $\begin{array}{l}\text { Organic } \\
\text { matter (g) }\end{array}$ \\
\hline \multirow{3}{*}{$10^{\circ}$} & 5 & $1.94 \pm 0.28$ & $0.85 \pm 0.16$ & $10.33 \pm 0.56$ & $0.28 \pm 0.08$ & $2.91 \pm 0.34$ & $0.071 \pm 0.01$ & $32.57 \pm 2.34$ \\
\hline & 10 & $3.54 \pm 0.36$ & $1.47 \pm 0.14$ & $19.08 \pm 1.65$ & $0.31 \pm 0.14$ & $5.77 \pm 0.36$ & $0.109 \pm 0.05$ & $58.56 \pm 5.52$ \\
\hline & 15 & $5.70 \pm 0.32$ & $2.38 \pm 0.22$ & $30.77 \pm 2.87$ & $0.50 \pm 0.22$ & $9.33 \pm 0.45$ & $0.177 \pm 0.04$ & $94.47 \pm 6.22$ \\
\hline \multirow{3}{*}{$20^{\circ}$} & 5 & $2.45 \pm 0.35$ & $1.02 \pm 0.16$ & $13.22 \pm 1.44$ & $0.37 \pm 0.10$ & $3.91 \pm 0.27$ & $0.077 \pm 0.02$ & $40.59 \pm 7.65$ \\
\hline & 10 & $4.59 \pm 0.42$ & $1.91 \pm 0.28$ & $24.75 \pm 2.56$ & $0.40 \pm 0.12$ & $7.46 \pm 0.52$ & $0.141 \pm 0.01$ & $75.98 \pm 7.84$ \\
\hline & 15 & $7.65 \pm 0.38$ & $3.19 \pm 0.34$ & $41.27 \pm 5.24$ & $0.66 \pm 0.18$ & $12.47 \pm 0.56$ & $0.237 \pm 0.03$ & $126.90 \pm 12.54$ \\
\hline \multirow{3}{*}{$30^{\circ}$} & 5 & $3.56 \pm 0.41$ & $1.52 \pm 0.36$ & $17.82 \pm 2.58$ & $0.35 \pm 0.12$ & $5.32 \pm 0.44$ & $0.125 \pm 0.05$ & $57.02 \pm 5.26$ \\
\hline & 10 & $6.21 \pm 0.46$ & $2.59 \pm 0.42$ & $33.48 \pm 2.43$ & $0.64 \pm 0.16$ & $10.07 \pm 0.62$ & $0.212 \pm 0.07$ & $102.80 \pm 9.56$ \\
\hline & 15 & $11.02 \pm 0.54$ & $4.58 \pm 0.48$ & $59.42 \pm 4.35$ & $0.96 \pm 0.22$ & $18.06 \pm 1.28$ & $0.341 \pm 0.08$ & $182.44 \pm 10.36$ \\
\hline
\end{tabular}

\subsection{Contribution of Zokor Destruction to Soil Erosion}

Figure 10 showed that the amount of soil loss in zokor degraded areas significantly increased after $60 \mathrm{~min}$ of rain at an intensity of $10 \mathrm{~mm} \mathrm{~h}^{-1}$ on a slope of $20^{\circ}$. A total of $1026.5 \mathrm{~g}$ of soil was lost from the whole plot area of zokor-denudated site at a rate of $256.6 \mathrm{~g} \mathrm{~m}^{-2} \mathrm{~h}^{-1}$. This figure dropped to $139.2 \mathrm{~g} \mathrm{~m}^{-2} \mathrm{~h}^{-1}$ at the vegetation-recovered site, and further to $14.5 \mathrm{~g} \mathrm{~m}^{-2} \mathrm{~h}^{-1}$ at the intact meadow site. Therefore, zokor activities caused a soil loss that was 1.8 times that of the vegetation-recovered site, and 17.7 times that of the intact meadow. These figures suggest that vegetation cover can effectively protect soil and reduce soil loss in the study area. Zokor burrowing severely aggravates soil loss. If the zokor outbreak is not brought under control, soil and water loss in the affected area will worsen rapidly, which will lead to extreme degradation of the alpine meadows.

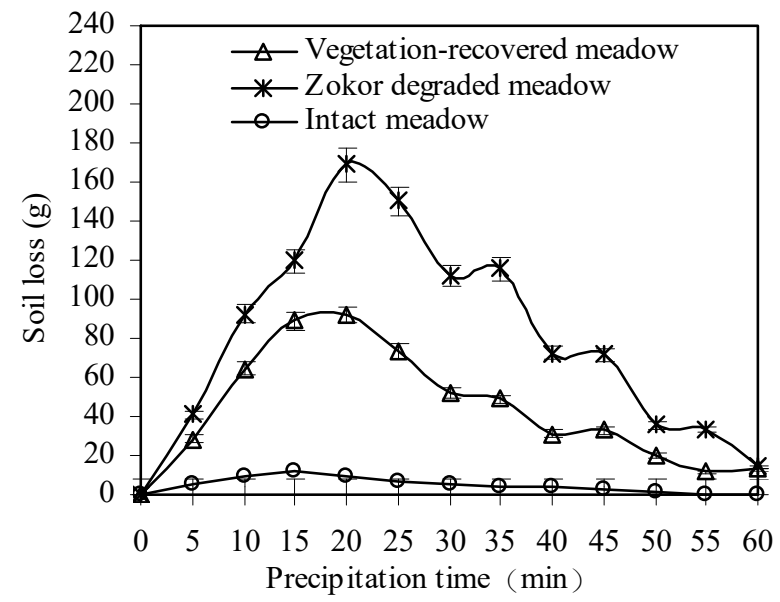

Figure 10. Comparison of soil loss from three types of surface covers. Results are based on a rainfall intensity of $10 \mathrm{~mm} \mathrm{~h}^{-1}$ on $20^{\circ}$ slopes.

\subsection{Soil Loss vs. Surface Runoff}

The rate of erosion depends largely on the transport capacity of runoff. As shown in Figure 11, the surface runoff curve with rainfall duration resembled those with the amount of soil loss in that it rose rapidly within the first 10 or $20 \mathrm{~min}$, depending on the slope gradient. However, these curves were different in that the rates decreased slowly and marginally with time, with little variation with slope gradient. The steeper the slope gradient, the greater the runoff produced by the rainwater. This relationship was influenced by inertia, and the larger the runoff, the greater the scouring force and transportation capacity of the runoff, the greater its transportation capacity. The loss of soil also increased on steeper slopes. Thus, it is very important to consider surface runoff when evaluating soil loss in degraded areas. 


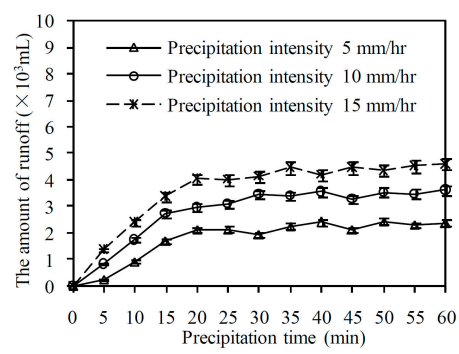

(a) $10^{\circ}$

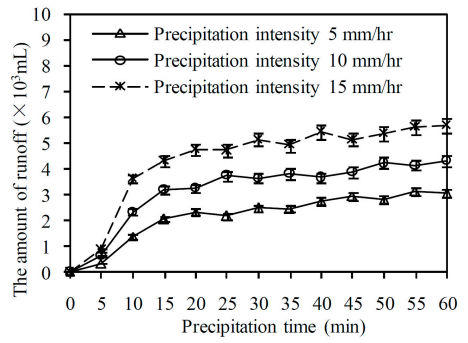

(b) $20^{\circ}$

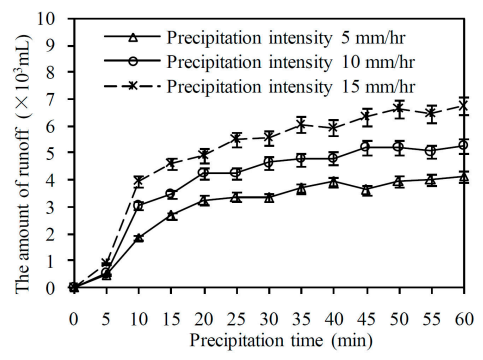

(c) $30^{\circ}$

Figure 11. The relationship between surface runoff and precipitation intensity at rainfall duration up to 60 min on mound surfaces of three gradients.

Within the $4 \mathrm{~m}^{2}$ zokor-denudated plot area, the relationship between the amount of soil loss (S) and surface runoff $(Q)$ also follows a power function, namely,

$$
S=0.2371 Q^{2.2307}\left(R^{2}=0.9529\right)
$$

This relationship is explained by the distribution of the rainfall. Initially, most of the rainwater is percolated down to the mound surface, leaving little rain to form surface runoff. However, as the surface is becoming increasingly saturated, an equilibrium between rainwater and surface runoff is reached at around 10-20 min. Afterwards, most of the rainfall is converted to surface runoff. As the rain prolongs, the portion of rainwater becoming surface runoff is approaching the rainfall.

\subsection{Soil loss vs. Particle Size}

The results indicated that fine soils were eroded regardless of the slope gradient and rainfall intensity. Their particle diameter ranged from 0 to $1.2 \mathrm{~mm}$ with a mean of $0.21 \mathrm{~mm}$. Of these soils, those with a diameter $<0.01 \mathrm{~mm}$ made up $1.65 \%$ of the total, those with a diameter of $0.01-0.05 \mathrm{~mm}$ made up $52.23 \%$, and those with a diameter of $0.05-1.20 \mathrm{~mm}$ made up $46.12 \%$. Apart from the total amount of soils, their loss from the mounds was also related to their particle size. The exact influence of rainfall intensity on particle size was variable with both rainfall intensity and duration (Figure 12). Within the first $20 \mathrm{~min}$ of rain, the mean diameter of the eroded soils rose rapidly. Afterwards, the diameter decreased slowly. On $20^{\circ}$ slopes, rainfall intensity exerted a subdued effect on the change in the diameter of soil particles. A more intensive rain caused the maximum diameter to rise from $0.31 \mathrm{~mm}$ at $5 \mathrm{~mm} \mathrm{~h}^{-1}$ to $0.47 \mathrm{~mm}$ at $10 \mathrm{~mm} \mathrm{~h}^{-1}$, and further to $0.58 \mathrm{~mm}$ at $15 \mathrm{~mm} \mathrm{~h}^{-1}$. This phenomenon is explained by the gradually rising driving force of the raindrops and surface runoff. This explains why there were more scattered fine particles on the surface of zokor mounds, and why the runoff increased within the first $20 \mathrm{~min}$ of rainfall (Figure 11). Loose particles less than $1.2 \mathrm{~mm}$ in diameter were rapidly transported under the impact of raindrops and runoff. The runoff tended to be stable after $20 \mathrm{~min}$ of rainfall (Figure 11), and the more scattered fine particles on the surface of zokor mounds were reduced, the more stable the soil structure became, and in turn the smaller the washed soil particles by the runoff became. Removal of more fine soils exposed the underlying plant roots. Their binding effects prevented soils from being eroded easily, causing the soil diameter to decrease. Also, the stronger the rainfall intensity was, the greater the driving force of surface runoff and soil erosion, causing the soil particle size to increase. 


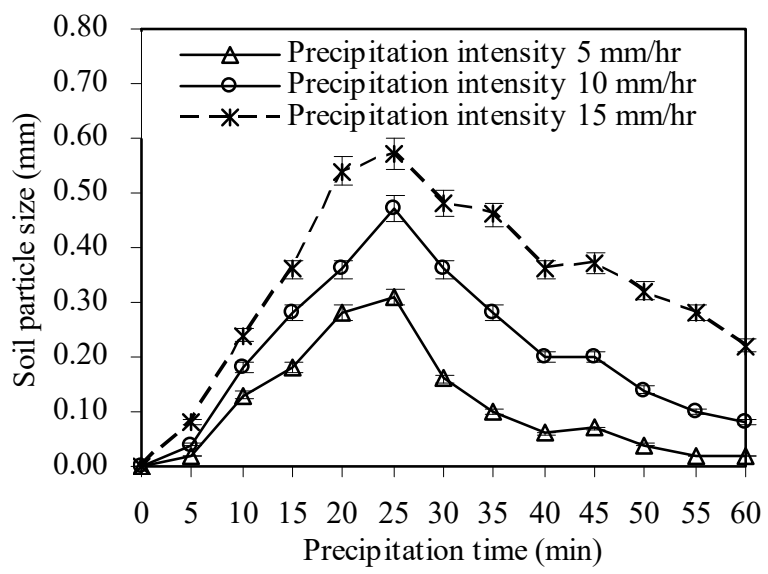

Figure 12. Variation in the particle size of eroded soils with the rainfall duration and intensity.

\section{Discussion}

\subsection{Importance of Vegetation Cover}

The zokor mounds in alpine meadows are loose deposits formed out of subsurface soil dug by burrowing zokors. Their erosion is affected by surface cover. In particular, vegetation reduces soil loss through its complex roots that are consumed by the small mammals within the soil. Through laboratory experiments, Pan et al. (2006) found that under the same rainfall conditions, grass significantly reduced eroded sediments by $81-95 \%$ in comparison with bare ground of a $15^{\circ}$ gradient [48]. Fullen et al. (2006) reported that soil aggregate stability was higher on grassed soils than on bare soils [49]. Wang et al. (2018) found that the sheet erosion rate decreased as vegetation cover increased, and herbaceous vegetation could reduce and control sheet erosion by reducing the effect of rainfall intensity or slope, especially when vegetation cover was sufficiently high [50]. In this study meadow cover reduced soil loss by 17.7 times on $20^{\circ}$ slopes. Even partially recovered vegetation to $60 \%$ reduced the soil loss by 1.8 times. Thus, vegetation cover could effectively reduce soil loss in both loess areas and in the study area. Apart from aboveground vegetation, both the grass root system and the soil crust also affect soil erosion. These issues need to be studied further in a separate paper. The related experiments in this paper were carried out only in one degraded area damaged by zokor, involving different rainfall intensities on different slopes. If the topography of the Yellow River Source Zone is known, the total amount of soil loss from the entire Source Zone and the erosion rate caused by zokor burrowing can be estimated from a combined consideration of zokor mound density and meteorological data using the method and results developed in this study. Another important area for further study is restoration ecology, namely, how burrowing zokors affect the prospects for ecological restoration of degraded meadows in the Yellow River Source Zone.

\subsection{Comparison with Other Studies}

In order to show the accelerated erosion of soil caused by zokor burrowing, the results obtained in this study were compared with those similar ones in other areas. Zhao et al. (2013) reported that the amount of soil loss from bare hillslopes in the hilly Loess Plateau of West China was 3.28 times higher than that from natural grasslands at a rainfall intensity of $120 \mathrm{~mm} \mathrm{~h}^{-1}$ [51]. Sediments were yielded at a rate 5.21 times higher at the rain intensity of $90 \mathrm{~mm} \mathrm{~h}^{-1}$. On $4 \%$ slopes under a rainfall intensity of 50 or $75 \mathrm{~mm} \mathrm{~h}^{-1}$ for 1 to $3 \mathrm{hr}$, soil was lost from hay fields at a rate ranging from 8 to $20 \mathrm{~g} \mathrm{~m}^{-2} \mathrm{~h}^{-1}$ in central North Dakota [52]. Again, these soil loss rates were only a tiny fraction of the loss rate of $256.6 \mathrm{~g} \mathrm{~m}^{-2} \mathrm{~h}^{-1}$ from the zokor mounds in spite of the much less intense rainfall. Zokor burrowing severely aggravates soil loss, and is a major accelerator of soil and nutrient loss from the meadows. Furthermore, Fang et al. (2013) found that more and more intensive gullies and textures appeared 
on the slope surface with the increasing of the gradient [53]. These findings are similar to the results shown in Figures 6 and 11.

\subsection{Effects of Plateau Zokor on Soil Nutrients}

The loss rate of soil nutrients increased with the increase of rainfall intensity and runoff, which is closely related to the change of the original soil structure and vegetation community when zokor burrowing [54]. This activity caused a large number of fine particles exposed on the surface of mound, which made it easy to be eroded by rainfall and runoff, resulting in nutrient loss and soil fertility reduction $[55,56]$. This also explained why soil nutrient loss increased with the severity of soil loss. In this study, the average loss of soil nutrients increased by 1.3 to 1.7 times when the slope increased from $10^{\circ}$ to $30^{\circ}$. Similar findings about nutrients loss caused by rainfall have also been reported by $\mathrm{Li}$ et al. (2013) who studied the loss of soil nutrition in a deteriorated alpine meadow. They reported that the soil nutrient loss decreased by $5.6-18.3 \%$ in moderately degraded areas, and by $12.2-44.7 \%$ in severely degraded areas when the slope increased from $10^{\circ}$ to $30^{\circ}$ [57]. Although the study area is different, their findings are similar to the results of this study (Table 2).

\subsection{Implications for Zokor Control and Soil Nutrients Restoration}

Zokor burrowing and soil erosion are critical causes of meadow degradation. In particular, soil excavation and transport by zokors destroy soil structure and meadows. If a zokor outbreak in alpine meadows would be not controlled, the soil loss rate in the affected area could increase rapidly, which could lead to the extreme degradation of alpine meadows. Therefore, the methods for controlling soil erosion are important to use for reducing the impact of zokors, which will reduce the zokor damage to the meadow. Furthermore, the restoration of the degraded meadow depended on the recovery of soil nutrients [58]. Considering the health ecosystem of alpine meadows, the restored measures of soil nutrients should aim at adding livestock manure to improve soil organic matter, so as to promote the effective restoration of the degraded meadows.

\section{Conclusions}

Both slope and rainfall intensity affected soil erosion of zokor mounds, but the slope had more of an influence than rainfall intensity on soil loss from the mounds. Soil loss occurred on the surface of zokor mounds $2 \mathrm{~min}$ after the simulated rainfall started. The highest rate of the soil loss occurred in the first $20 \mathrm{~min}$. Afterwards, the soil loss gradually decreased and the runoff remained constant after $20 \mathrm{~min}$ of precipitation. The soil loss increased with the increases of the rainfall intensity and slope gradient. The rapid flow of surface runoff enhanced soil erosion and nutrient loss. The zokor mounds were eroded at a rate of 1.8 times that of degraded meadows, and 17.7 times that of intact meadows, which indicated that zokors significantly accelerated the soil erosion. In order to restore the degraded meadows, controlling zokors should be combined with adding livestock manure to achieve the dual purpose of preventing and controlling soil erosion in alpine meadows.

Author Contributions: This research was conceptualized by G.L., X.L. and J.L. during the funding acquisition. The methodology for the field investigation was a joint effort of G.L., and X.L., J.L., W.C., H.Z. and J.Z. were responsible for the collection and analysis of field data. G.L. wrote the first draft of the paper. X.L. and X.H. contributed in reviewing and editing the manuscript.

Funding: This research was funded by Natural Science Foundation of China (Grant no. 41662023, 31872999, 41762023), Qinghai Science and Technology Department (Grant no.2016-ZJ-728, 2017-HZ-802), and the 111 Project (Grant No. D18013).

Acknowledgments: The authors thank undergraduate students C.L., Y.C., J.Q. and H.W. for data collection in the field. G.J. from University of Auckland provided insightful comments on the original manuscript, and gave constructive guidance and valuable help of the manuscript. Thanks are extended to anonymous reviewers and the Editor for useful comments that improved the manuscript. Thanks to the numerous teachers and students who have worked with us and have profoundly influenced the ideas presented in this paper.

Conflicts of Interest: The authors declare no conflict of interest. 


\section{References}

1. Hu, G.Y.; Dong, Z.B.; Lu, J.F.; Yan, C.Z. Spatial and temporal changes of desertification land and its influence factors in source region of the Yellow River from 1975 to 2005. J. Desert Res. 2011, 31, 1079-1086. (In Chinese)

2. Li, X.L.; Gao, J.; Brierley, G.J. Rangeland degradation on the Qinghai-Tibet Plateau: Implications for rehabilitation. Land Degrad. Dev. 2013, 24, 72-80. [CrossRef]

3. Liu, Y.S.; Fan, J.W.; Shi, Z.J.; Yang, X.H.; Harris, W. Relationships between plateau pika (Ochotona curzoniae) densities and biomass and biodiversity indices of alpine meadow steppe on the Qinghai-Tibet Plateau China. Ecol. Eng. 2017, 102, 509-518. [CrossRef]

4. $\quad$ Fan, J.W.; Shao, Q.Q.; Liu, J.Y.; Wang, J.B.; Harris, W.; Chen, Z.Q.; Zhong, H.P.; Xu, X.L.; Liu, R.G. Assessment of effects of climate change and grazing activity on grassland yield in the Three Rivers Headwaters Region of Qinghai-Tibet Plateau, China. Environ. Monit. Assess. 2010, 170, 571-584. [CrossRef] [PubMed]

5. Yi, X.S.; Li, G.S.; Yin, Y.Y.; Wang, B.L. Preliminary study for the influences of grassland degradation on soil water retention in the source region of the Yellow River. J. Nat. Resour. 2012, 27, 1708-1719. (In Chinese)

6. Brierlye, G.; Li, X.L. Editorial: Geomorphology and environmental management of the Yellow River source zone. J. Mt. Sci. 2013, 10, 628-631. [CrossRef]

7. Wang, Q.J.; Shi, H.L.; Jing, Z.C.; Wang, C.T.; Wang, F.G. Recovery and benefit analysis of ecology on degraded natural grassland of the source region of Yangze and Yellow rivers. Pratacultural Sci. 2004, 21, 37-41. (In Chinese with English abstract).

8. White, R.; Murray, S.; Rohweder, M. Pilot Analysis of Global Ecosystems: Grassland Ecosystems; World Resour. Institute: Washington, DC, USA, 2000; ISBN 1-56973-461-5.

9. Pang, X.P.; Guo, Z.G. Plateau pika disturbances alter plant productivity and soil nutrients in alpine meadows of the Qinghai-Tibetan Plateau, China. Rangel. J. 2017, 39, 133-144. [CrossRef]

10. Wu, R.X.; Chai, Q.; Zhang, J.Q.; Zhong, M.Y.; Liu, Y.H.; Wei, X.T.; Pan, D.; Shao, X.Q. Impacts of burrows and mounds formed by plateau rodents on plant species diversity on the Qinghai-Tibetan Plateau. Rangel. J. 2015, 37, 117-123. [CrossRef]

11. Pech, R.P.; Jiebu Arthur, A.D.; Zhang, Y.M.; Lin, H. Population dynamics and responses to management of plateau pikas. Ochotona curzoniae. J. Appl. Ecol. 2007, 44, 615-624. [CrossRef]

12. Sun, D.; Zheng, J.H.; Ma, T.; Chen, J.J.; Li, X. The analysis of burrows recognition accuracy in Xinjiang's pasture area based on UAV visible images with different spatial resolution. Int. Arch. Photogramm. Remote Sens. Spat. Inf. Sci. 2018, 42, 1575-1579. [CrossRef]

13. Chen, J.J.; Yi, S.H.; Qin, Y. The contribution of plateau pika disturbance and erosion on patchy alpine grassland soil on the Qinghai-Tibetan Plateau: Implications for grassland restoration. Geoderma 2017, 297, 1-9. [CrossRef]

14. Zhou, L.Z.; Li, D.Q.; Wang, X.L.; Ma, Q. Sanjiangyuan Reserve's rodent pests, their damage to frigid meadows and the control strategies. J. Anhui Univ. 2002, 26, 87-96. (In Chinese with English abstract).

15. Ma, Y.; Lang, B.; Shi, D. Establishing pratacultural system: A strategy for rehabilitation of 'black soil type' deteriorated grassland on the Qinghai-Tibetan Plateau. In Formation and Evolution, Environment Changes and Sustainable Development on the Tibetan Plateau; Zheng, D., Zhu, L.P., Eds.; Academy Press: Beijing, China, 2000; pp. 334-339. (In Chinese with English abstract).

16. Zhang, Y.M. Influence of Plateau Zokors (Eospalax fontanierii) on Alpine Meadows. In Subterranean Rodents; Springer: Berlin, Germany, 2007; pp. 301-308.

17. Walker, L.R.; Vrooman, S.S.; Thompson, D.B. Rodent mounds facilitate shrubs and shrubs inhibit seedlings in the Mojave Desert, USA. J. Arid Environ. 2015, 113, 95-101. [CrossRef]

18. Yu, C.; Zhang, J.; Pang, X.P.; Wang, Q.; Zhou, Y.P.; Guo, Z.G. Soil disturbance and disturbance intensity: Response of soil nutrient concentrations of alpine meadow to plateau pika bioturbation in the Qinghai-Tibetan Plateau, China. Geoderma 2017, 307, 98-106. [CrossRef]

19. Yu, C.; Pang, X.P.; Wang, Q.; Jin, S.H.; Shu, C.C.; Guo, Z.G. Soil nutrient changes induced by the presence and intensity of plateau pika (Ochotona curzoniae) disturbances in the Qinghai-Tibet Plateau, China. Ecol. Eng. 2017, 106, 1-9. [CrossRef]

20. Limbach, W.; Davis, J. The introduction of sustainable development practices of the Qinghai livestock development project. In Formation and Evolution, Environment Changes and Sustainable Development on the Tibetan Plateau; Zheng, D., Zhu, L.P., Eds.; Academy Press: Beijing, China, 2000; pp. 509-522. 
21. Zhou, H.K.; Zhao, X.Q.; Tang, Y.H.; Gu, S.; Zhou, L. Alpine grassland degradation and its control in the source region of the Yangtze and Yellow Rivers, China. Grassl. Sci. 2005, 51, 191-203. [CrossRef]

22. Miehe, G.; Miehe, S.; Kaiser, K.; Liu, J.Q. Status and dynamics of the Kobresia pygmaea ecosystem on the Tibetan Plateau. AMBIO 2008, 37, 272-279. [CrossRef]

23. Wu, H.L.; Liu, S.M. Ecological environment situation in the Yellow River Source Zone. Pratacultural Anim. Husb. 2011, 7, 42-43. (In Chinese)

24. Erpul, G.; Gabriels, D.; Norton, L.D.; Flanagan, D.C.; Huang, C.H.; Visser, S.M. Mechanics of interrill erosion with wind-driven rain. Earth Surf. Process. Landf. 2013, 38, 160-168. [CrossRef]

25. Meshesha, D.T.; Tsunekawa, A.; Tsubo, M.; Haregeweyn, N.; Adgo, E. Evaluation of kinetic energy and erosivity potential of simulated rainfall using Laser Precipitation Monitor. Catena 2016, 37, 237-243. [CrossRef]

26. Wang, B.; Steiner, J.; Zheng, F.L.; Gowda, P.H. Impact of rainfall pattern on interrill erosion Process. Earth Surf. Process. Landf. 2017, 42, 1833-1846. [CrossRef]

27. Nearing, M.A.; Simanton, J.R.; Darrell, N.L.; Bulygin, S.J.; Stone, J. Soil erosion by surface water flow on a stony, Semiarid hillslope. Earth Surf. Process. Landf. 1999, 24, 677-686. [CrossRef]

28. Berger, C.; Schulze, M.; Rieke-Zapp, D.; Schlunegger, F. Rill development and soil erosion: A laboratory study of slope and rainfall intensity. Earth Surf. Process. Landf. 2010, 35, 1456-1467. [CrossRef]

29. Palmer, R.C.; Smith, R.P. Soil structural degradation in SW England and its impact on surface-water runoff generation. Soil Use Manag. 2013, 29, 567-575. [CrossRef]

30. Carollo, F.G.; Stefano, C.D.; Ferro, V.; Pampalone, V.; Sanzone, F. Testing a new sampler for measuring plot soil loss. Earth Surf. Process. Landf. 2016, 41, 867-874. [CrossRef]

31. Zhao, L.S.; Huang, C.H.; Wu, F.Q. Effect of microrelief on water erosion and their changes during rainfall. Earth Surf. Process. Landf. 2016, 41, 579-586. [CrossRef]

32. Aksoy, H.; Eris, E.; Tayfur, G. Empirical sediment transport models based on indoor rainfall simulation and erosion flume experimental data. Land Degrad. Dev. 2017, 28, 1320-1328. [CrossRef]

33. Momm, H.G.; Wells, R.R.; Bennett, S.J. Disaggregating soil erosion processes within an evolving experimental landscape. Earth Surf. Process. Landf. 2018, 43, 543-552. [CrossRef]

34. Fullen, M.A. A comparison of runoff and erosion rates on bare and grassed loamy sand soils. Soil Use Manag. 1991, 7, 136-139. [CrossRef]

35. Morvan, X.; Naisse, C.; Issa, O.M.; Desprats, J.F.; Combaud, A.; Cerdan, O. Effect of ground-cover type on surface runoff and subsequent soil erosion in Champagne vineyards in France. Soil Use Manag. 2014, 30, 372-381. [CrossRef]

36. Gessesse, B.; Bewket, W.; Bräuning, A. Model-based characterization and monitoring of runoff and soil erosion in response to land use/land cover changes in the Modjo Watershed, Ethiopia. Land Degrad. Dev. 2015, 26, 711-724. [CrossRef]

37. Arthur, A.D.; Pech, R.P.; Jiebu, Z.Y.; Lin, H. Grassland degradation on the Tibetan Plateau: The role of small mammals and methods of control. Aust. Cent. Int. Agric. Res. Tech. Rep. 2007, 67, 1-35.

38. Li, X.L.; Perry, G.L.W.; Brierley, G.; Gao, J.; Zhang, J.; Yang, Y.W. Restoration prospects for Heitutan degraded grassland in the Sanjiangyuan. J. Mt. Sci. 2013, 10, 687-698. [CrossRef]

39. Auerswald, K.; Fiener, P.; Dikau, R. Rates of sheet and rill erosion in Germany-Ameta-Analysis. Geomorphology 2009, 111, 182-193. [CrossRef]

40. Wirtz, S.; Seeger, M.; Ries, J.B. Field experiments for understanding and quantification of rill erosion processes. Catena 2012, 91, 21-34. [CrossRef]

41. Zhou, X.R.; Guo, X.G.; Guo, X.H. The role of plateau pika and plateall zokor in alpine meadow. Pratacultural Sci. 2010, 27, 38-44. (In Chinese)

42. Liu, Y.S.; Fan, J.W.; Harris, W.; Shao, Q.Q.; Zhou, Y.C.; Wang, N.; Li, Y.Z. Effects of plateau pika (Ochotona curzoniae) on net ecosystem carbon exchange of grassland in the Three Rivers Headwaters region, Qinghai-Tibet, China. Plant Soil 2013, 366, 491-504. [CrossRef]

43. Sun, F.D.; Long, R.J.; Guo, Z.G.; Liu, W.; Gan, Y.M.; Chen, W.Y. Effects of rodents activities on plant community and soil environment in alpine meadow. Pratacultural Sci. 2011, 28, 146-151. (In Chinese)

44. Wang, T.C.; Xiong, Y.C.; Ge, J.P.; Wang, S.M.; Li, Y.T.; Yue, D.X.; Wang, T.M.; Wang, G. Four-year dynamic of vegetation on mounds created by zokors (Myospalax baileyi) in a subalpine meadow of the Qinghai-Tibet Plateau. J. Arid Environ. 2008, 72, 84-96. [CrossRef] 
45. Harris, R.B. Rangeland degradation on the Qinghai-Tibetan Plateau: A review of the evidence of its magnitude and causes. J. Arid Environ. 2010, 74, 1-12. [CrossRef]

46. Zhang, W.H.; Miao, Y.J.; Zhao, Y.H.; Wang, X.T.; Xu, Y.M.; Wei, X.H.; Sun, L. Effects of plateau pika (Ochotona curzoniae) on alpine meadow in Tibet. Acta Prataculturae Sin. 2018, 27, 115-122. (In Chinese)

47. Bao, S.D. Soil and Agricultural Chemistry Analysis; China Agricultural Press: Beijing, China, 2000; ISBN 9787109066441. (In Chinese)

48. Pan, C.Z.; Shangguan, Z.P. Runoff hydraulic characteristics and sediment generation in sloped grassplots under simulated rainfall conditions. J. Hydrol. 2006, 331, 178-185. [CrossRef]

49. Fullen, M.A.; Booth, C.A. Grass ley set-aside and soil organic matter dynamics on sandy soils in Shropshire, UK. Earth Surf. Process. Landf. 2006, 31, 570-578. [CrossRef]

50. Wang, D.D.; Wang, Z.L.; Zhang, Q.W.; Zhang, Q.L.; Tian, N.L.; Liu, J.E. Sheet erosion rates and erosion control on steep rangelands in loess regions. Earth Surf. Process. Landf. 2018, 43, 2926-2934. [CrossRef]

51. Zhao, X.N.; Wu, P.T.; Chen, X.L.; Helmers, M.J.; Zhou, X.B. Runoff and sediment yield under simulated rainfall on hillslopes in the Loess Plateau of China. Soil Res. 2013, 51, 50-58. [CrossRef]

52. Zheng, F.L.; Merrill, S.D.; Huang, C.H.; Tanaka, D.L.; Darboux, F.; Liebig, M.A.; Halvorson, A.D. Runoff, soil erosion, and erodibility of conservation reserve program land under crop and hay production. Soil Sci. Soc. Am. J. 2004, 68, 1332-1341. [CrossRef]

53. Fang, H.Y.; Sun, L.Y.; Tang, Z.H. Effects of rainfall and slope on runoff, soil erosion and rill development: An experimental study using two loess soils. Hydrol. Process. 2015, 29, 2649-2658. [CrossRef]

54. Bessler, H.; Temperton, V.M.; Roscher, C.; Buchmann, N.; Schmid, B.; Schulze, E.D.; Weisser, W.W.; Engels, C. Aboveground overyielding in grassland mixtures is associated with reduced biomass partitioning to belowground organs. Ecology 2009, 90, 1520-1530. [CrossRef]

55. Wu, W.Z.; Zhou, Q.; Yu, B.; Ma, C. Characteristics of soil erosion in Three Rivers' sources natural reserve. J. Mt. Sci. 2009, 27, 683-687. [CrossRef]

56. Wang, Q.L.; Wang, C.T.; Liu, W.; Cao, G.M.; Long, R.J. Changes in plant communities and soil microbial physiological groups of artificial grasslands established for different years in headwater region of Yangtze River and Yellow River. Chin. J. Appl. Ecol. 2009, 20, 2646-2651. (In Chinese)

57. Li, G.R.; Li, X.L.; Chen, W.T.; Li, J.F.; Zhu, H.L.; Zhong, L.Z. Influences of rain erosion on soil nutrient contents of the deteriorated grassland. Res. Soil Water Conserv. 2018, 25, 40-45. (In Chinese)

58. Ruiz-Jaen, M.C.; Aide, T.M. Restoration success: How is it being measured. Restor. Ecol. 2005, 13, 569-577. [CrossRef] 